of using the fires as an excuse to gain access to larger trees that are more commercially valuable, but are not part of the wildfire problem.

Meanwhile, the west is bracing itself for what could be its worst fire season in decades. Already, 2.8 million acres nationwide have burned, compared with 1.6 million in the first half of 2000 , which ended with 8.4 million acres destroyed, the most in 40 years. The problem gets worse each year, with more suburban encroachment into forested areas complicating efforts to contain fires, and increasing their economic and human costs.

Julio Betancourt, a research scientist with the US Geological Survey's Desert Laboratory in Tucson, Arizona, who is studying the ecology of the desert southwest, warns that if the region goes into a prolonged drought lasting years - and climatologists see signs that this may be happening — the situation will become even worse. And fires aren't the end of it, he says. When monsoon rains come to Arizona later this month, as they do every summer, run-off from the now barren landscape is likely to lead to serious erosion and flooding.

Betancourt and other scientists worry that even with more money for research, and a more determined effort to eliminate hazardous fuels, this may be too little, too late. According to a report by the Joint Fire Science Program, it "may be possible" to treat 5 million acres a year, but with more than 100 million acres at risk from fire nationwide, "it is uncertain whether this treatment level is adequate to reverse the trend of increasing fuel accumulations and begin to reduce wildland fire problems".

\title{
Visitors to AIDS conference trapped in web of red tape
}

\section{Declan Butler, Paris}

A row over the availability of visas for visitors from developing nations is casting a shadow over the 14th International AIDS Conference, which opens in Barcelona on 7 July.

Scientists and journalists from several countries, including India, Colombia and the Democratic Republic of the Congo, say that they have had their visa applications blocked or delayed by local Spanish embassy officials.

Earlier this year, the Spanish foreign ministry contacted its embassies around the world asking them to expedite visas for participants in the conference who meet certain requirements, such as having medical insurance and sufficient money to return home.

But the message failed to get through, according to Lars Kallings, secretary-general of the Stockholm-based International AIDS Society, one of the conference's organizers. Kallings says that visa applications have been hampered by bureaucracy, and that staff at various embassies and consulates have been unhelpful. Some applicants have complained that the entry requirements are excessive, Kallings says, whereas others allege that wealthier tourists have been given priority for the fixed quotas of available visas.

John Mokili, a Congolese postdoc who is currently working at the Los Alamos National Laboratory in New Mexico, says that he has only just received his visa - a month after he applied for it. The process should normally take a day. As of 1 July, he says, only one of 14 other Congolese researchers had their visas.

And of 72 journalists from developing nations offered scholarships to attend a training programme on reporting on HIV, only 25 have their visas, says Laurie Garrett, a New York-based journalist helping to organize it.

Kallings says that the situation could look as though Spain has breached its contract to host the conference without discrimination. He points out that the United States remains blacklisted as a venue for the conference after similar problems in 1985 and 1987.

Conference organizers have pressed the Spanish government to redress the situation and one organizer, Javier Rubio, says a list of registered participants has now been circulated to Spain's embassies and a fresh effort is under way to speed up visa applications.

www.aids2002.com

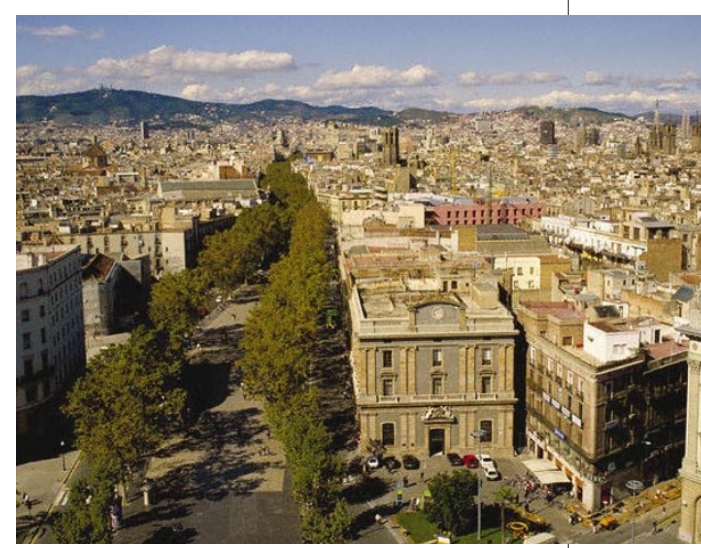

No entry: delegates from developing nations are finding it hard to gain access to Barcelona.

\section{Gulf War syndrome research poised for cash injection}

\section{Jonathan Knight, San Francisco}

The US government is set to give research into Gulf War syndrome a sharp increase in funds following advice from scientists who believe that ill veterans suffered neurological damage during the 1991 conflict.

On 25 June, an advisory panel appointed by veterans' affairs secretary Anthony Principi concluded that research into whether neurological damage had been caused by vaccination or exposure to nerve agents "should be aggressively pursued", and recommended that Congress commit $\$ 450$ million over three years to the project.

The administration of President Bill Clinton tended to play down the idea that nerve gas or vaccines might have caused the health problems reported by some veterans, calling evidence of any link inconclusive.
Instead, it maintained that the most likely cause was traumatic stress.

But during his election campaign, President George W. Bush promised to investigate evidence of such links, and he has since appointed officials, such as Principi, who are sympathetic to the veterans' claims.

The science of Gulf War syndrome has changed little over the years, however. Epidemiological studies have shown that more Gulf War veterans suffer symptoms such as dizziness compared with other veterans, but a decade of research has failed to find a single 'syndrome', or its cause.

In September 2000, an Institute of Medicine panel reviewed 1,000 research papers and concluded that there was insufficient evidence to support a link between nerve agents and veterans' symptoms (see Nature 407, 121; 2000).

The advisory panel, which included several researchers whose work has pointed to a neurological cause of Gulf War syndrome, is urging that the new money should be administered by the National Institutes of Health. Panel member Robert Haley, director of epidemiology at the University of Texas Southwestern Medical Center at Dallas, says that the defence department cannot be trusted to address the issue fairly. Haley believes that exposure to chemicals may have caused brain damage in some veterans (see Nature 385, 187; 1997).

But Gregory Gray, an epidemiologist at the University of Iowa who has studied the problem, says: "A lot of sharp investigators have already looked at this. I'm sceptical that more studies will show anything different." 